\title{
Low Melting Carat Gold Brazing Alloys for Jewellery Manufacture
}

\author{
A STUDY OF Ag-Au-Ge-Si ALLOYS
}

\author{
G. Zwingmann \\ DEgussa, Hanau, West Germany
}

The Au-Ag-Ge-Si system has been investigated as a source of cadmium-free low melting carat gold hard solders but alloys of this type have been found to have restricted applicability. In particular, when applied to copper-containing alloys, brittle copper germanides and silicides are formed.

The brazing alloys which are used in the manufacture of gold jewellery and related products must meet a number of requirements. Not only must the colour of the solder in each case match that of the alloys which are being joined as closely as possible, but its composition must be such that the final article conforms to hallmarking or related specifications. These vary from country to country and in Germany they permit in the case of nonjewellery articles a tolerance of 0.5 per cent, and in the case of gold jewellery a tolerance of 1.0 per cent in respect of the overall fineness or caratage stamped on the product. If it is desired to use a hard solder with a gold content lower than that of the alloys which are being bonded together, the gold contents of the latter must therefore be increased in order to compensate for the lower concentration of the gold in the hard solder. In general, however, it is preferred where possible to use a solder of the same fineness or caratage as the materials to which it is being applied. Accordingly, carat gold solders are normally sold in the same caratages $(18,14,10,9$ and 8$)$ and colours as are carat golds themselves.

Additionally, however, manufacturers supply carat gold solders with a range of different working temperatures in each caratage and colour. This enables the craftsman or manufacturer to choose an appropriate solder in each instance, and in particular to use solders in appropriate succession when a number of soldering operations have to be carried out in close proximity to one another on the one article. To achieve the combinations of properties called for, base metals such as zinc and cadmium have usually been incorporated in $\mathrm{Ag}-\mathrm{Au}-\mathrm{Cu}$ alloys. Cadmium is a useful addition where low working temperatures are called for, but its use is not desirable because of the toxicity of the fumes to which it gives rise.

The aim of the present study was to develop carat gold brazing alloys, for the manufacture of jewellery and precious metal wares in each of the recognised caratages, which were free of cadmium and which had working temperatures in the range $400-600^{\circ} \mathrm{C}$.

\section{Literature}

The information about their products which is released by suppliers of carat gold solders relates mainly to their melting behaviours or working temperatures. Working temperatures for 8 carat gold solders range approximately from $700^{\circ} \mathrm{C}$ (first solders) to $640^{\circ} \mathrm{C}$ (third solders), for 14 carat gold solders from $780^{\circ} \mathrm{C}$ (first solders) to $670^{\circ} \mathrm{C}$ (third solders), and for 18 carat gold solders from $820^{\circ} \mathrm{C}$ (first solders) to $700^{\circ} \mathrm{C}$ (third solders). In no instance are solders with working temperatures below $600^{\circ} \mathrm{C}$ available.

Data concerning the compositions of their solders are not normally released by manufacturers but it is apparent from the work of Lüder (1) and from data made available by one manufacturer that most carat gold hard solders contain from 2.6 to 20 per cent $\mathrm{Cd}$.

Information is more fully available, however, concerning the compositions of gold solders applied industrially and Wuich (2) has described the application in the electronics industry of gold solders which melt at significantly lower temperatures than $600^{\circ} \mathrm{C}$. Mention may be made for example of the Au-Sn solder containing 20 per cent $\mathrm{Sn}$, which melts at $280^{\circ} \mathrm{C}$, and of the eutectic Au-Ge alloy containing 12 per cent Ge, which melts at $356^{\circ} \mathrm{C}$. Such alloys are, however, for the most part brittle and are not available in caratages which would make them suitable for 
jewellery applications. Although certain gallium bearing gold alloys (3) are of interest in this connection, no gold alloys have in fact been identified so far which can be adjusted in composition to the caratages of carat golds as used in jewellery and which would have working temperatures when used as solders of between $400^{\circ} \mathrm{C}$ and $600^{\circ} \mathrm{C}$.

A survey of various binary systems (Hansen and Anderko (4), Elliot (5) and Shank (6)) reveals that most gold alloys which have sufficiently low liquidus temperatures are either composed predominantly of brittle intermetallic phases or else have gold contents far removed from those of the accepted carat golds. Where solid solutions are formed with gold, these have liquidus temperatures which are far too high.

The Au-Ge and Au-Si systems are an exception to this rule, in that they are purely eutectic in character. The same is true of the $\mathrm{Ag}-\mathrm{Ge}$ and $\mathrm{Ag}-\mathrm{Si}$ systems. Since the Ag-Au system consists of a continuous series of solid solutions, it follows that no eutectic four phase equilibrium can develop in either the $\mathrm{Ag}-\mathrm{Au}-\mathrm{Ge}$ or $\mathrm{Ag}-\mathrm{Au}-\mathrm{Si}$ systemș. $\mathrm{A}$ continuous binary eutectic curve traverses the diagram of each of these ternary systems between the two binary eutectic temperatures. In the $\mathrm{Ag}-\mathrm{Au}-\mathrm{Ge}$ system the eutectic liquidus temperatures lie accordingly between $651^{\circ} \mathrm{C}$ and $350^{\circ} \mathrm{C}$, and in the $\mathrm{Ag}-\mathrm{Au}-\mathrm{Si}$ system between $810^{\circ} \mathrm{C}$ and $370^{\circ} \mathrm{C}$.

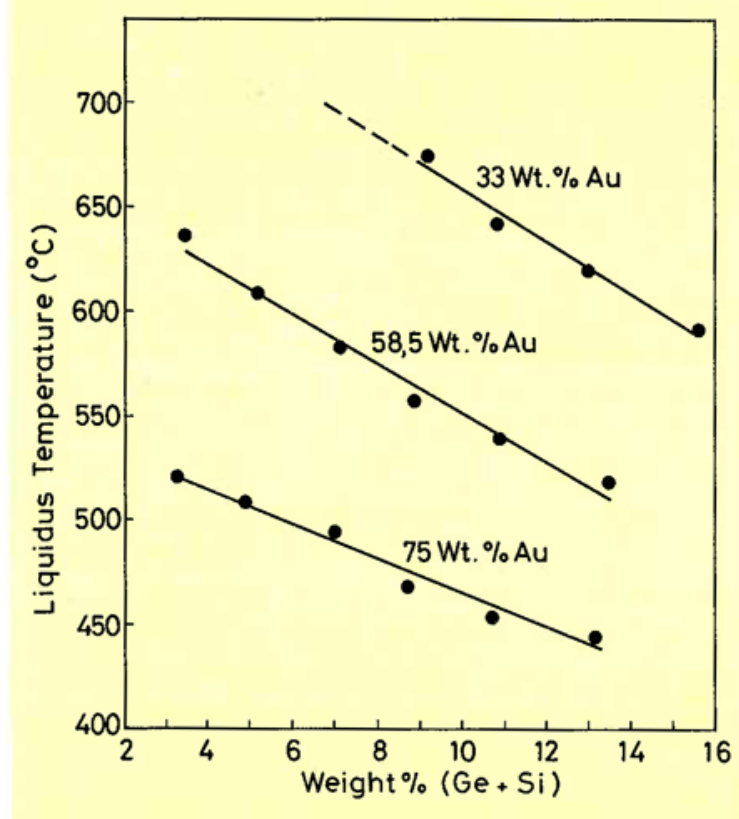

Fig. 1 Temperature of the liquidus of Au-AgGe-Sialloys as a function of their $(\mathrm{Ge}+\mathrm{Si})$ contents
The phase relationships for the ternary $\mathrm{Ag}-\mathrm{Au}-\mathrm{Si}$ system have been investigated by Kuprina (7) and those of the Ag-Au-Ge system by Zwingmann (8). From their studies it may be deduced that eutectic alloys with finenesses of 333, 585 and 750 (i.e. caratages of 8,14 and 18) should have liquidus temperatures either just inside or outside the desired upper limit of $600^{\circ} \mathrm{C}$. Generally speaking, the eutectic temperatures of the $\mathrm{Ag}-\mathrm{Au}-\mathrm{Ge}$ alloys are significantly lower than those of the Ag-Au-Si alloys. On the one hand, however, the Ge-contents of the eutectic $\mathrm{Ag}-\mathrm{Au}-\mathrm{Ge}$ alloys are significantly higher than the Si-contents of the eutectic Ag-Au-Si alloys, so that the former alloys tend to be less workable, while on the other hand the Au-Si alloys (Wise (9), Predecki, Giessen and Grant (10), and Philofsky, Ravi, Brooks and Hall (11)) have a tendency to solidify in metastable forms which can also result in brittleness.

It was decided therefore to investigate whether, in the quaternary $\mathrm{Ag}-\mathrm{Au}-\mathrm{Ge}-\mathrm{Si}$ system, alloys with more suitable properties could be identified for use as carat gold hard solders.

\section{Course of the Investigations}

Three series of alloys were prepared containing respectively 33.3, 58.5 and $75 \mathrm{wt}$. per cent of gold. Within each series, and for a series of Ge contents of from 0-15.6 wt. per cent, Ag-Au-Ge-Si alloys of different Si-contents were subjected to thermal analysis and microscopical examination in order to determine firstly the liquidus temperatures and secondly the compositions of the eutectic alloys.

In the case of selected alloys the effects upon the liquidus temperatures of further additions of $\mathrm{Cu}$, $\mathrm{Ga}, \mathrm{In}, \mathrm{Sn}$ or $\mathrm{Zn}$ were studied. At the same time the behaviour of the alloys during deformation was examined and their working temperatures determined. Soldering tests were also carried out and the solder layer studied with an electron microprobe.

\section{Results}

\section{Eutectic Liquidus Temperatures}

The results of the examination of the cooling curves and microstructures of the various alloys are summarized in Figure 1 and the Table. In Figure 1 eutectic liquidus temperatures at constant gold contents are plotted against the concentrations of $\mathrm{Ge}+\mathrm{Si}$ in the alloys. This shows how the liquidus temperatures of eutectic Ag-Au$\mathrm{Ge}-\mathrm{Si}$ alloys, at each of the three levels of gold content studied, fall linearly with their $\mathrm{Ge}$ or $\mathrm{Ge}+\mathrm{Si}$ contents.

The range of liquidus temperatures stretches 
from $520^{\circ} \mathrm{C}$ to $445^{\circ} \mathrm{C}$ for 18 carat alloys, from $635^{\circ} \mathrm{C}$ to $520^{\circ} \mathrm{C}$ for 14 carat alloys, and from about $750^{\circ} \mathrm{C}$ to $590^{\circ} \mathrm{C}$ for 8 carat alloys. Because the aim was to produce alloys with working temperatures of less than $600^{\circ} \mathrm{C}$, studies of 8 carat alloys with $\mathrm{Ge}$-contents of less than 7.5 per cent were not pursued.

From these results it is apparent that both 750 fineness (18 carat) and 585 fineness (14 carat) $\mathrm{Ag}-\mathrm{Au}-\mathrm{Ge}-\mathrm{Si}$ alloys with liquidus temperatures below $600{ }^{\circ} \mathrm{C}$ are available, and that the lowest liquidus temperatures of the 18 carat alloys are at the same level as the highest liquidus temperatures of the 14 carat alloys. In contrast, however, the corresponding temperatures for the 8 carat alloys are in general greater than $600^{\circ} \mathrm{C}$. The liquidus temperatures fall with increase in $\mathrm{Ge}$ content, which is accompanied by a fall in the level of Si-content of the eutectic composition.

Study of the cooling curves has further revealed that in spite of the relatively slow rate of cooling during thermal analysis, equilibrium is not established between the solid solutions of $\mathrm{Ag}-\mathrm{Au}$ and $\mathrm{Ge}-\mathrm{Si}$ which occur in the system. In consequence the observed solidus temperatures are lower than the true values. Thus solidification of alloys containing 75 per cent of gold ends only at $360^{\circ} \mathrm{C}$.

Mechanical Workability of Eutectic Ag-Au-Ge-Si Alloys

All the alloys listed in the Table were melted in an induction furnace under argon and cast into round rods of $9 \mathrm{~mm}$ diameter.

None of the samples so prepared could be cold rolled in the as-cast condition. However, with the exception of the 18 carat alloy of highest $\mathrm{Ge}$ content, all the cast rods could be rolled after pre-heating to temperatures ranging from $400^{\circ} \mathrm{C}$ (for 18 carat alloys) to $550^{\circ} \mathrm{C}$ (for 8 carat alloys). After hot rolling, most of the alloys could be further cold worked to strains varying between 30 and $60 \%$, depending on the contents of $\mathrm{Ge}+\mathrm{Si}$. Details are presented in the Table.

The fact that the alloys show limited susceptibility to deformation after hot rolling, even though they show no ductility in the as-cast condition, can be explained in terms of their structures. During the thermo-mechanical treatment the crystals of Ge-Si solid solution globulize, as may be seen in Figures 2 and 3. Figure 2 shows the acicular microstructure of $\mathrm{Ge}-\mathrm{Si}$ in the as-cast

Table

Composition and Properties of Eutectic Ag-Au-Ge-Si Alloys

\begin{tabular}{|c|c|c|c|c|c|c|c|c|}
\hline $\begin{array}{l}\text { Composition } \\
\% \text { by weight } \\
\mathrm{Ag} / \mathrm{Au} / \mathrm{Ge} / \mathrm{Si}\end{array}$ & $\begin{array}{c}\mathrm{Ge}+\mathrm{Si} \\
\% \text { by weight }\end{array}$ & $\begin{array}{c}\text { Liquidus } \\
\text { Temperature } \\
{ }^{\circ} \mathrm{C}\end{array}$ & $\begin{array}{c}\text { Working } \\
\text { Temperature } \\
{ }^{\circ} \mathrm{C}\end{array}$ & $\begin{array}{l}\text { Calculated } \\
\text { Density } \\
\mathrm{g} / \mathrm{cm}^{3}\end{array}$ & Colour & \multicolumn{3}{|c|}{$\begin{array}{l}\text { Workability } \\
\text { hot cold }\end{array}$} \\
\hline 57.5/33.3/ 7.5/1.7 & 9.2 & 675 & 670 & 10.7 & white & yes & approx. & $50 \%$ \\
\hline $55.9 / 33.3 / 10.0 / 0.8$ & 10.8 & 642 & 630 & 10.8 & " & $"$ & " & $30 \%$ \\
\hline $53.7 / 33.3 / 12.5 / 0.5$ & 13.0 & 620 & 600 & 10.6 & $"$ & $"$ & & no \\
\hline $51.1 / 33.3 / 15.6 /-$ & 15.6 & 593 & 580 & 10.5 & $"$ & " & & no \\
\hline $38.0 / 58.5 /-/ 3.5$ & 3.5 & 636 & 620 & 12.3 & $\begin{array}{c}\text { yellowish } \\
\text { white }\end{array}$ & yes & approx & $60 \%$ \\
\hline $36.3 / 58.5 / 2.5 / 2.7$ & 5.2 & 608 & 600 & 12.3 & " & " & " & $50 \%$ \\
\hline $34.4 / 58.5 / 5.0 / 2.1$ & 7.1 & 582 & 570 & 12.3 & " & " & " & $50 \%$ \\
\hline $32.6 / 58.5 / 7.5 / 1.4$ & 8.9 & 557 & 560 & 12.3 & $" \prime$ & " & " & $40 \%$ \\
\hline $30.6 / 58.5 / 10.0 / 0.9$ & 10.9 & 540 & 530 & 12.2 & $"$ & " & " & $30 \%$ \\
\hline $28.0 / 58.5 / 13.5 /-$ & 13.5 & 519 & 500 & 12.1 & $"$ & $"$ & & no \\
\hline $21.7 / 75.0 /-/ 3.3$ & 3.3 & 520 & 500 & 13.6 & yellow & yes & approx. & $60 \%$ \\
\hline $20.1 / 75.0 / 2.5 / 2.4$ & 4.9 & 508 & 500 & 13.7 & " & " & " & $50 \%$ \\
\hline $18.0 / 75.0 / 5.0 / 2.0$ & 7.0 & 495 & 470 & 13.5 & " & $"$ & " & $40 \%$ \\
\hline $16.3 / 75.0 / 7.5 / 1.2$ & 8.7 & 468 & 450 & 13.6 & $"$ & " & " & $40 \%$ \\
\hline $14.3 / 75.0 / 10.0 / 0.7$ & 10.7 & 455 & 450 & 13.5 & " & " & " & $30 \%$ \\
\hline $11.8 / 75.0 / 13.2 /-$ & 13.2 & 445 & - & 13.4 & " & no & & no \\
\hline
\end{tabular}




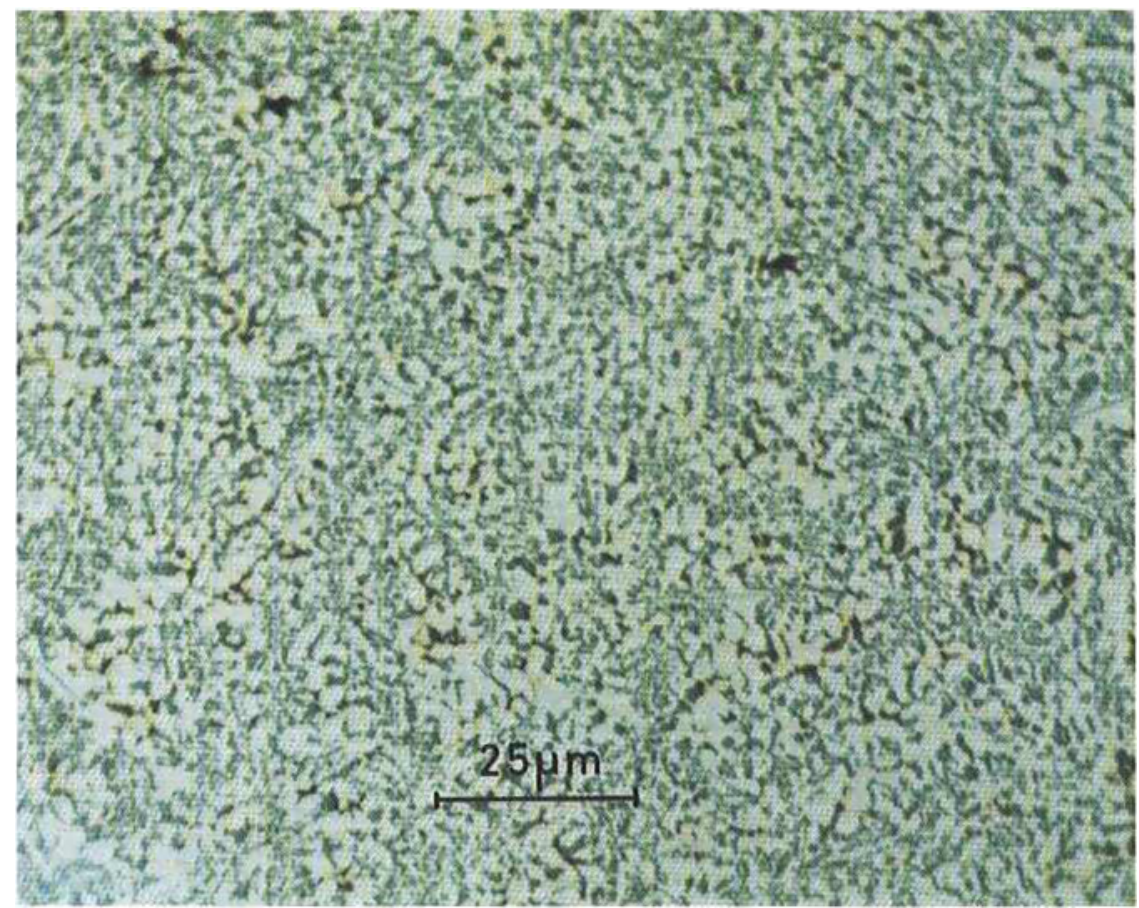

Fig. 2 Microstructure of a $58.8 \mathrm{Au} / 32.6 \mathrm{Ag} / 7.5 \mathrm{Ge} / 1.4 \mathrm{Si}$ wt. per cent alloy in the ascast condition. Unetched

sample, while Figure 3 shows the roundish appearance of the grains after hot deformation.

The Effect of Further Additions Upon Liquidus Temperature

A portion (2.5 wt. per cent) of the silver in the $18 \mathrm{Ag} / 75 \mathrm{Au} / 5 \mathrm{Ge} / 2 \mathrm{Si}$ and the $20.1 \mathrm{Ag} / 75 \mathrm{Au} / 2.5$
$\mathrm{Ge} / 2.4 \mathrm{Si}$ alloys was replaced by $\mathrm{Cu}, \mathrm{Ga}, \mathrm{In}, \mathrm{Sn}$ and $\mathrm{Zn}$ respectively. Thermal analysis and microstructural studies established that in each case this resulted in a displacement of equilibria and pure eutectic alloys were no longer obtained. As a result the liquidus temperature (except in the case of copper addition) was raised $50-100^{\circ} \mathrm{C}$. Similar

Fig. 3 Microstructure of a 58.5 Au/32.6 Ag/7.5 Ge/1.4 Si wt. per cent alloy after hot rolling. Unetched

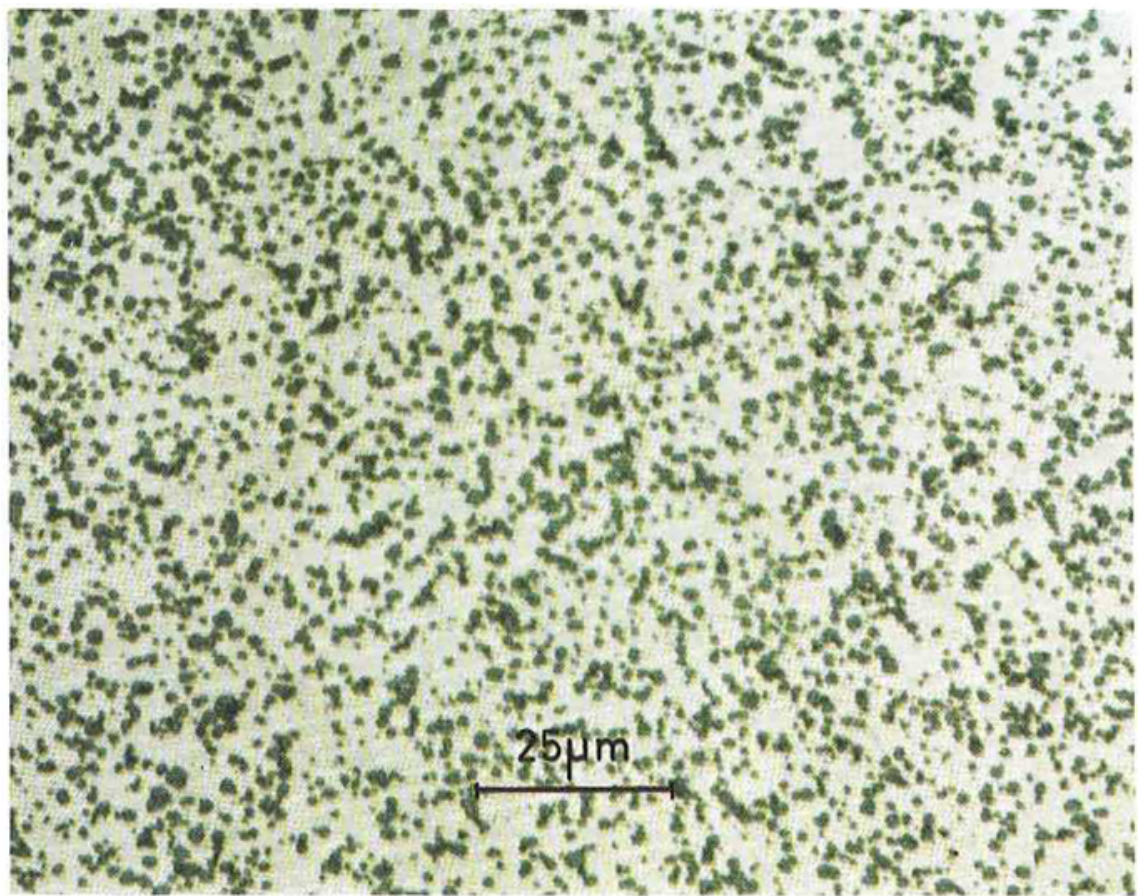




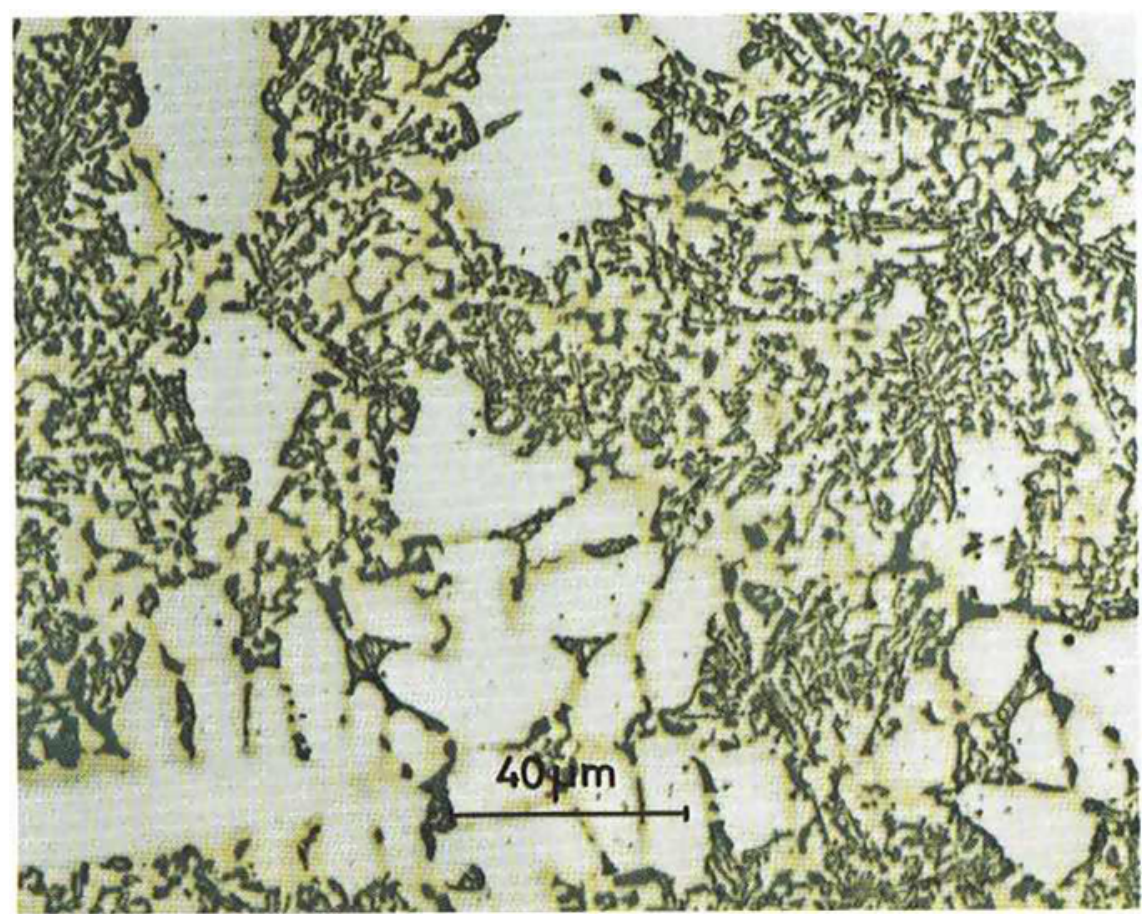

Fig. 4 Microstructure of a $75 \mathrm{Au} / 20.1 \mathrm{Ag} / 2.5 \mathrm{Ge} / 2.5 \mathrm{Si}$ wt. per cent solder joint on Cu-free 18 ct gold. Sodium thiosulphate electroetched

results were obtained when the gold content was held constant and the added metals content varied in such a manner that pure eutectic alloys were again obtained. Except in the case where $\mathrm{Cu}$ was the metal added, the eutectic temperatures were either not affected or else somewhat raised.

Only the addition of $\mathrm{Cu}$ resulted in a lowering (about $20^{\circ} \mathrm{C}$ ) of the liquidus temperature. This addition of $2.5 \mathrm{wt}$. per cent $\mathrm{Cu}$ led, however, at all three caratages, to such strong embrittlement of the base alloy that it could no longer be hot rolled.

\section{Working Temperature}

The determination of the so-called working temperature (i.e. the temperature at which the solder flows with a specified flux) was carried out according to a somewhat modified form of the procedure of Loebich (12). The flux used was DEGUSSA Flux C. The results of the measurements are presented also in the Table. It is apparent that the working temperatures are only a little $\left(<20^{\circ} \mathrm{C}\right)$ below the liquidus temperatures of the individual alloys, even though the difference between the liquidus and solidus temperatures is significantly greater. For example, the ranges of temperature over which crystallisation of the 18 carat alloys occurs are between $95^{\circ} \mathrm{C}$ and $160^{\circ} \mathrm{C}$.

\section{Soldering studies}

Using alloys of all the three caratages studied, both butt and $\mathrm{T}$-joints were soldered between commercial gold jewellery alloys of corresponding caratages. The soldering was carried out both under laboratory conditions and in collaboration with a goldsmith.

The results may be summarized as follows:

(1) Soldering is possible with all three types of solder

(2) The solders do not flow quite as well as might be desired, and the joints improve with decreasing fineness

(3) The solder joints are too brittle. After they are established they can no longer be deformed

The finding that the bonding improves with decreasing fineness (and therefore with increasing working temperature) indicates that the working temperature of the flux used was not low enough for the alloys of higher fineness.

Although it was to be anticipated from the studies of the workability of the alloys that joints made from them would show limited ductility only, embrittlement to the extent observed was unexpected.

Metallographic investigations established that the microstructure of the solder in the joint differed considerably from that of the original cast rods. Electron microprobe studies were 
Fig. 5 Microstructure of a $75 \mathrm{Au} / 20.1 \mathrm{Ag} / 2.5 \mathrm{Ge} / 2.4 \mathrm{Si}$ wt. per cent solder joint on Cu-containing 18 ct gold. Sodium thiosulphate electroetched

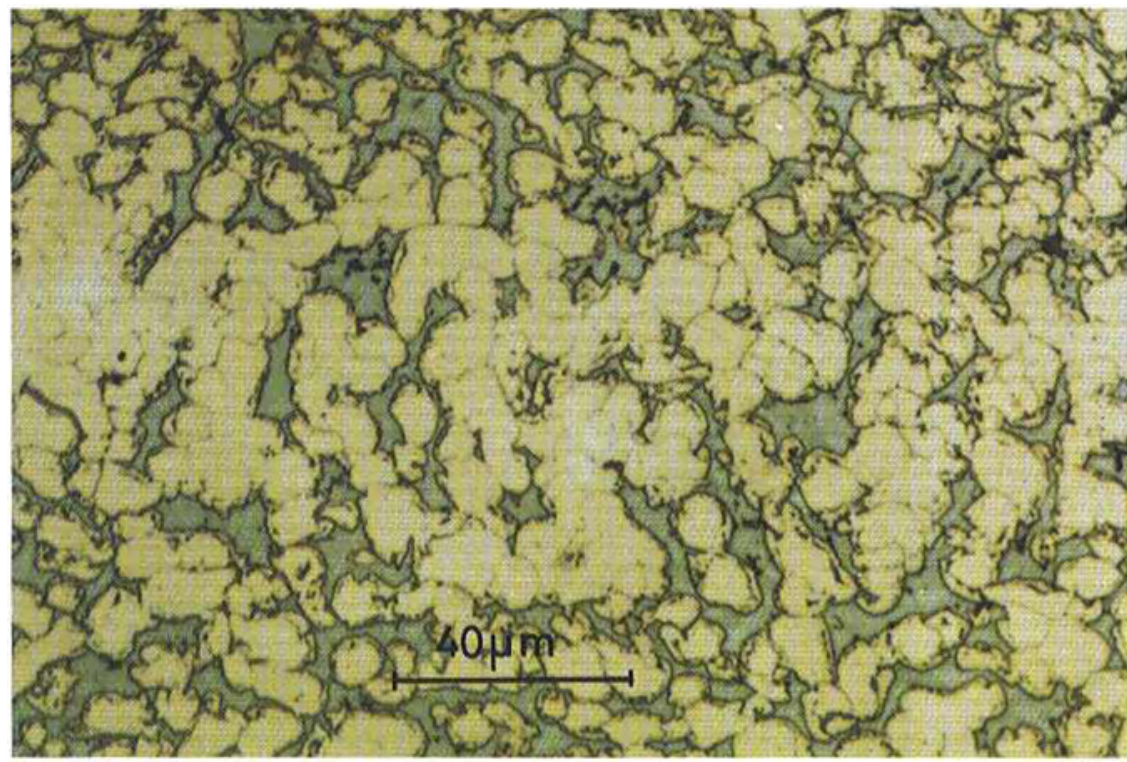

therefore carried out in order to establish the reasons for the very pronounced embrittlement of the solder joints. These investigations gave the same result with the alloys of each degree of fineness; namely:

(1) The solder in the joints contained considerable amounts of $\mathrm{Cu}$

(2) Free Ge and Si were present in the solder joints only in small amounts

(3) All the components in the solder in which Ge and/or Si were present also contained large amounts of $\mathrm{Cu}$

From these finding it may be deduced that when $\mathrm{Cu}$-containing alloys are soldered with $\mathrm{Ag}-\mathrm{Au}-$ $\mathrm{Ge}-\mathrm{Si}$ alloys, the $\mathrm{Ge}$ and $\mathrm{Si}$ in the solder alloy react preferentially with the $\mathrm{Cu}$ of the alloys which are being soldered to form copper germanides and copper silicides. As a result a ternary phase possibly develops. Since the copper germanides and silicides are brittle compounds, it is understandable that plastic deformation of the resulting joint is not possible. This explanation finds support in the fact that when foils of $\mathrm{Au}-\mathrm{Ag}$ binary alloys of various caratages were butt-soldered, the resulting joints could in general be deformed by 50 to 60 per cent by rolling before the solder joint developed cracks.

The microstructure of a soldered joint on a $\mathrm{Cu}$-free $\mathrm{Au}-\mathrm{Ag}$ alloy is illustrated in Figure 4 and that of a joint on a $\mathrm{Cu}$-containing $\mathrm{Au}-\mathrm{Ag}$ alloy in Figure 5. Significant differences can be observed. In the case of $\mathrm{Cu}$-free material (Figure 4), the solder essentially retains a eutectic structure, whereas in the case of Figure 5, only isolated crystals of $\mathrm{Ge}$ or $\mathrm{Si}$ remain within a matrix consisting of $\mathrm{Cu}$ germanides and silicides.

\section{Conclusions}

The investigations have shown that in the quaternary $\mathrm{Ag}-\mathrm{Au}-\mathrm{Ge}-\mathrm{Si}$ system there exist series of 18 carat and 14 carat eutectic compositions which meet all requirements set out earlier in respect of working temperature, hallmarking, workability and freedom from $\mathrm{Cd}$. In the case of 8 carat alloys of this type, however, the working temperatures of the eutectic compositions exceed $600^{\circ} \mathrm{C}$. These alloys can certainly be used for soldering of $\mathrm{Cu}$-free gold alloys, even when a measure of ductility is wanted in the solder joint. They can, however, be used for soldering of $\mathrm{Cu}-$ containing gold alloys only if no deformation of the joint is contemplated after it has been made.

\section{Acknowledgements}

We thank the Chamber of Mines of South Africa and the International Gold Corporation Limited for their support of these investigations.

\section{References}

1 E. Lüder, 'Handbuch der Löttechnik', Verlag Technik, Berlin, 1952

2 W. Wuich, 'Löten', Vogel-Verlag, Würzburg, 1972

3 J. S. Hatswell and M. H. Sloboda, (Johnson Matthey \& Co., Ltd), U.S. Patent 3,892,564, 1975

$4 \mathrm{M}$. Hansen and K. Anderko, 'Constitution of Binary Alloys', McGraw-Hill Book Co., New York, 1958

5 R. P. Elliot, 'Constitution of Binary Alloys', First Supplement, McGraw-Hill Book Co., New York, 1965

6 F. A. Shunk, 'Constitution of Binary Alloys', Second Supplement, McGraw-Hill Book Co., New York, 1965

7 V. V. Kuprina, Russ. F. Inorg. Chem., 1962, 7, (7), 833-834

8 G. Zwingmann, Metall., 1964, 18, (7), 726-727

9 E. M. Wise, 'Gold: Recovery, Properties and Applications', D. van Nostrand Co., Princeton, 1964

10 P. Predecki, B. C. Giessen and N. J. Grant, Trans. AIME, 1965, 233, (7), 1438-1439

11 E. Philofsky, K. V. Ravi, J. Brooks and E. Hall, f. Electrochem. Soc., 1972, 119, (4), 527-530

12 O. Loebich, Metall., 1951, 5, (23-24), 548-550 